\title{
Towards a history of Melanesian archaeological practices
}

\author{
Matthew Spriggs
}

To be ignorant of what occurred before you were born is to remain always a child. For what is the
worth of human life, unless it is woven into the life of our ancestors by the study of history.

-Cicero, Orator, 120

There are obvious advantages to understanding the history of our discipline, as it is the intellectual baggage we all bring to the trowel's edge, whether we know it or not, and whether we have absorbed it consciously or unconsciously from our teachers and peers. This was brought home to me when reading the Kulturkreis archaeologist/ethnologist Robert Heine-Geldern's account of Austronesian migrations into the Pacific, written nearly 90 years ago (Heine-Geldern 1932). There seemed little difference to me, including the use of the word Austronesian, between his general outline of migration and interaction and what one can find today in a general work such as Peter Bellwood's latest survey (2017). There has been nearly a century of Pacific archaeology since Heine-Geldern wrote, with a particular acceleration in research over the last 50 years or so, and yet the basic narrative arguably remains the same. This can only be either because he precociously got the story right or, alternatively, because his schema was so influential in organising knowledge as archaeology developed in the region that we have never managed to question its basic direction.

We clearly need more of what David Clarke (1973) called in another archaeological context 'critical self-consciousness' to examine whether the bases of our explanations are in fact grounded in unthinking and outmoded ways of thought, perhaps colonialist, imperialist and/or racialised. As George Santayana (1905:284) put it in an oft-quoted but ironically otherwise depressingly racist passage: 'those who cannot remember the past are condemned to repeat it'. Critical selfconsciousness of our intellectual past, however, goes beyond just understanding the background to the master narratives of the discipline in the Pacific. We cannot understand the old excavation and survey reports that we all build on in our work without knowing what techniques and practices were available at the time to be deployed in constructing the details of prehistory that we take for granted today, and what sort of lag there was between the availability and the take-up of particular analytical techniques. This can give us an idea of how networked or isolated Pacific archaeology has been during its history with regards to global developments in the field. This in turn reflects back on our larger-scale grand narratives, by asking what building blocks were used to construct them; what tools and materials could be deployed at particular times in developing the Pacific archaeologist's theoretical superstructure? 
This paper will not delve into the history of the wider theoretical frameworks that we use to organise our data, the subject being too vast to cover here, but it will illustrate the point made above about the availability of particular scientific practices and techniques. It will provide a few select case studies concerning when particular techniques were first available, when they were first deployed in Pacific archaeology more generally and when in the archaeology of the Melanesian region in particular. Certain kinds of evidence-based discussions were not possible until particular technical advances in practice in archaeological science were deployed; some questions simply could not be asked.

Radiocarbon dating is the obvious place to start the discussion, and then the lead is given by the three themes for the volume identified by the editors. I will draw illustrations from each of these in turn, before using this history to evaluate the networked or isolated status of archaeology in our region at particular times. The themes lend themselves to the examination of particular facets of our discipline. The first, 'Landscapes and complexities', requires an engagement with settlement patterns and landscape archaeology. The second, 'Exchange and contacts', relies on characterisation and provenance studies of such artefacts as stone adzes, pottery and obsidian flakes. I will use this as my primary 'case study' and cover the topic in most detail. The final theme, 'Practices', involves such topics as manufacturing sequences, environmental reconstruction and funerary (bio)archaeology. Has there been a slow unfolding of knowledge or were there particular, perhaps serendipitous, moments that have shaped the course of archaeological investigation?

\section{The radiocarbon revolution}

One such defining moment was surely the invention of radiocarbon dating by Willard Libby and colleagues in the late 1940s, becoming potentially available to archaeologists throughout the world around 1949-50. It was very quickly deployed by Pacific archaeologists, with Bishop Museum archaeologist Kenneth Emory getting the first date back from a Polynesian archaeological site in 1950, the Kuli'ou'ou rock shelter on O'ahu, Hawaii. It was published originally on 21 September 1951 in the second date list from Libby's laboratory at the University of Chicago, along with two Australian archaeological samples collected by Edmund Gill from Victorian middens (Libby 1951). Melanesia was not far behind with Edward Winslow Gifford publishing multiple dates from two significant Fijian sites he had excavated in 1947 and judiciously kept the charcoal from (Gifford 1952, 1955, as anticipated in his earlier monograph [1951:203]), and then from his 1952 New Caledonia excavations, including at the site of Lapita (Crane 1956; Gifford and Shutler 1956:89-92). In this case we can see very little lag between the invention of the technique and its Pacific and Melanesian deployment. ${ }^{1}$

\footnotetext{
1 It is also worth noting that the first radiocarbon laboratory in the Pacific region was established in 1951 and later became known as the Rafter Laboratory at Lower Hutt, New Zealand, named in honour of its founder, Athol Rafter. It is currently the world's oldest continuously operating radiocarbon laboratory (www.gns.cri.nz/Home/Services/Laboratories-Facilities/Rafter-RadiocarbonLaboratory/About-Us/The-History-of-Rafter). The second such laboratory was established at the Museum (later Institute) of Applied Science in Melbourne and opened officially in 1961 after a long set-up period beginning in 1954 and with advice from Athol Rafter, but it had continual equipment problems and closed in 1970 (Rae 2018). A dating facility was also established at the University of New South Wales in the early 1960s but only produced one date list before closing (Green et al. 1965). The third was that set up at The Australian National University in 1965 by Henry Polach, who had transferred from Rafter's New Zealand Laboratory (Mulvaney 1993:22).
} 
It must be recalled that prior to the development of radiocarbon dating, Pacific chronologies relied upon oral traditions and genealogical dating; there simply were no other methods beyond putative links of pottery styles in the Pacific to those in other parts of the world (invariably wrong in hindsight), or the superficial resemblance of particular artefact types to supposed 'Palaeolithic' tools and thus suggestive of a deep antiquity (Kirch 2017). An interesting history could be written, although this is not the place to present it, of the increasingly long vistas opened up by the development of a 'deep time' history that radiocarbon dating allowed in the very largely unglaciated Pacific; in Europe it was the geological record of past glaciations that had created a framework for a Pleistocene prehistory from the late 19th century onwards (Daniel 1975). In our part of the world the general belief, albeit with some notable early exceptions, ${ }^{2}$ was that prehistory had been, if not necessarily nasty and brutish, certainly short. We started with a thousand-year history in Hawaii; with the Fijian radiocarbon dates it became 2000 years for Melanesia, and in New Caledonia by 1956 it was approaching 3000 years (Gifford and Shutler 1956). The first dates from New Guinea in the 1960s pushed Pacific chronology back to over 10000 years (Bulmer 1964a), ${ }^{3}$ reaching 26000 BP (uncalibrated) by 1970 (White et al. 1970). The first Pleistocene date in Island Melanesia was obtained in 1981 by Jim Specht with a date from Misisil on New Britain in the Bismarck Archipelago (Specht et al. 1981, 1983). It was from 1993 that a reliable means of calibrating radiocarbon dates back into the Pleistocene was established (Stuiver and Reimer 1993), ultimately to allow extension back to the limits of the method in 2009 (Reimer et al. 2009).

The radiocarbon barrier at about 40000 years (now extended by calibration a few thousand years earlier (Summerhayes et al. 2010)) was first breached in New Guinea by the discovery of waisted axes in stratigraphic position on the Huon Terraces in 1986 by Les Groube and his students, dated using thermoluminescence to 60 000-40 000 years (Groube et al. 1986); Uranium series dating later confirming the age of the marine terrace on which this deposit sits to be 61000 52000 years old (Chappell et al. 1994). For comparison, in Australia the barrier was breached only in 1990 at the site now known as Madjedbebe, initially using thermoluminescence but later the more developed optically stimulated luminescence (OSL), most recently on single sand grains (Clarkson et al. 2017; Roberts et al. 1990, 1993).

The results of the 1984-85 Lapita Homeland Project (Allen and Gosden 1991) pushed Island Melanesian occupation back towards 40000 years on New Ireland in the Bismarcks, with later results providing potentially even older dates for New Britain using OSL (Torrence et al. 2004). A project developing directly out of the Lapita Homeland Project pushed the dates on Buka Island in the neighbouring Solomons back to 28000 BP (uncalibrated) (Wickler and Spriggs 1988). And there the Pleistocene frontier in Melanesia has remained, with no dates earlier than c. 3000 BP from anywhere in Remote Oceania to date, despite concentrated efforts during the 1990s and early 2000s in Vanuatu to look for earlier settlement there (Bedford and Spriggs 2008). The Pleistocene frontier that we are confident of today between Near and Remote Oceania was thus only firmly established in the early years of the 21 st century.

The point is that to evaluate statements made about the archaeology of the Pacific at any particular date, we need to know what chronological models and constraints those writing them were living under at the time. They simply did not know what we know now.

2 Fritz Sarasin went to New Caledonia in search of Palaeolithic 'river drift man' in 1911-12, without success (Sarasin 2009 [1929]). Alphonse Riesenfeld posed the question in the 1950s of whether there was a Pleistocene history in Melanesia (Riesenfeld 1952). Neither intervention had any significant influence on subsequent archaeological practice, however.

3 Recall that in Australia a terminal Pleistocene prehistory had only been securely established in 1962 (Mulvaney 2011:113). 


\section{Landscapes and complexities: Settlement patterns and landscape archaeology in the Pacific}

Roger Green is generally credited with introducing a settlement pattern approach to the Pacific, derived from his Harvard background in the 1950s, where he was taught by Gordon Willey who was a major American pioneer in such studies (Willey 1953). Green's Harvard classmate, Kwang-Chih Chang was later to write a standard text, Settlement Patterns in Archaeology (1972; see also Chang 1958). In a perceptive paper that deserves a wider audience Phillips and Campbell (2004) survey the field in New Zealand, but with further reference to the Pacific, providing a history which covers the range of approaches from the original settlement pattern approach to what is now called landscape archaeology. They refer to the claim of Parsons (1972:134) that the Pacific regional 'school' of settlement archaeology, led by Green, was the first anywhere outside the United States. But they also note some earlier applications of somewhat similar methods by scholars such as HD Skinner, and the British contribution via figures such as Cyril Fox (1923) and OGS Crawford (1953) that was part of the intellectual baggage brought to New Zealand by Golson in 1954 as 'field archaeology' (Golson 1957b; Golson and Green 1959; see also Golson 1986). They also recognise the novel developments of the approach by others in New Zealand, including Les Groube in particular (partially published in Groube 1965).

Green was also very influential in Hawaii, where he was based at the Bishop Museum from 1966 to 1970 , helping to initiate large-scale settlement pattern surveys, particularly of the various dryland field systems at Lapakahi on Hawai i $i$ Island, and irrigated and dryland systems at Makaha in O'ahu and at Halawa Valley on Moloka'i (Kirch 1985:18-19).

Aerial photography has long been a staple technique of Pacific geographers. Its first explicitly archaeological applications were called for by Blake-Palmer (1947) in New Zealand, citing the pioneering work in Britain by OGS Crawford (1928) and others. Blake-Palmer called for an archaeologist to be attached to the New Zealand Survey Department so that the many Maori sites visible on aerial photographs could be placed on maps. Golson (1957b) also noted the value of aerial photography in surveys. Its first sustained use in Melanesia in examining prehistoric settlement patterns was by the geographer John Parry in Fiji. Covering particularly deltaic and swampy areas he was able to identify fortified settlements and also agricultural features. This research was published in a series of papers between 1977 and 1997 (see Parry 1977, 1997 for examples and references). Similar work was carried out in New Caledonia on the irrigated taro terraces and other agricultural systems there (Roux 1990, reporting on early 1980s work).

Landscapes (and seascapes) have also been foci in Melanesia more recently, seen by Phillips and Campbell as deriving mainly from British post-processual approaches: they note particularly Ballard (1994) and Gosden and Pavlides (1994). Such an influence was clearly there but they miss the strong influence from human and cultural geography associated with scholars such as Brookfield and Hart (1971) and Bonnemaison (1974, 1979). The former influenced several generations of New Guinea archaeologists at The Australian National University (ANU) and elsewhere, and the latter was a particular influence on those working in Vanuatu (for instance Spriggs 1985, 1987 [orig. 1981]).

Most recently, the deployment of aerial laser scanning or LiDAR (light detection and ranging) imagery in the Pacific and elsewhere, literally 'seeing' beneath the trees to pick out even subtle human alterations in the landscape, has opened up interpretive vistas almost impossible to imagine even a few years ago. The technology particularly took off in the remote sensing literature at the very end of the 20th century and archaeological applications began to appear in the first decade of the current one (Barnes 2003; Bewley 2003; Bewley et al. 2005; Devereux et al. 2005). Spectacular results have come particularly from tropical regions (Chase et al. 2012 
for Mesoamerica, and Evans et al. 2014 for the Angkor Wat complex in Cambodia). First use in Pacific archaeology appears to have been in Hawaii in 2011 (Ladefoged et al. 2011; McCoy et al. 2011), American Samoa in 2015 (Quintus et al. 2015) and Tonga in 2016 (Freeland et al. 2016). Entire cultural landscapes are being revealed, previously 'lost' under heavy vegetation or otherwise scarcely visible to the naked eye in cleared cattle paddocks - such as recently investigated on the island of Efate in central Vanuatu (Bedford et al. 2018). The latter research revealed the unsuspected extent of dryland intensified agricultural systems and a hitherto undescribed site type of large circular earthworks whose function is at present unknown.

Previous achievements in settlement pattern and landscape archaeology in the Pacific have been rather overshadowed by the LiDAR revolution. The earlier shift in attention, however, from single sites to sites within a natural and cultural landscape, and to the investigation of settlement hierarchies and other features of settlement patterns, were what created the frameworks for understanding newly deployed techniques. The open landscapes of parts of Fiji which allowed Parry to use extensive aerial photographic coverage in many ways prefigured current LiDAR developments. Without such wide-scale coverage of settlements within their cultural and agricultural landscapes, issues of prehistoric demography and agricultural intensification could not be seriously addressed. Already the Efate and Vanuatu LiDAR data can be used to suggest much higher population densities at European contact than previously demonstrable (Bedford et al. 2018). The tragedy of catastrophic population declines due to introduced Western diseases is thus more starkly brought into focus.

\section{Exchange and contacts: The history of characterisation and provenance studies}

Characterisation is the act of discriminating between artefacts derived from different sources, whereas provenance hazards at least a guess as to where the sources might be. A precocious chemical analysis of jade artefacts was published in 1865 in Paris by Damour, from an explicitly archaeological science perspective (Damour 1865). It seems to have been very largely overlooked by historians of archaeology—-the only archaeological reference in English to this work I can find is in W Campbell Smith's work on 'Jade axes from sites in the British Isles' (Smith 1963:151-152). Damour's work is particularly notable as the chemical analyses included a nephrite axe from New Zealand, and the study included further axes claimed to be from the Marquesas, as well as an obsidian artefact from Easter Island. ${ }^{4}$

Thin sections of pottery from Peru, and from Santorini in the Greek Mediterranean, of Greek and of Mexican obsidian were being undertaken in the 1880s and 1890s (references from Cann et al. 1969; Matson 1969). Petrology was to become a staple of provenance studies of British Neolithic axes from the 1930s onwards (Grimes 1979), and of North American pottery from at least the 1930s (Keiller et al. 1941; Kidder and Shepard 1936).

In the late 1940s Gifford had tried to secure the services of Anna O Shepard (unsuccessfully) to thin section pottery from his Fijian excavations. ${ }^{5}$ He got some interest from his geologist colleague Howel Williams, but the work was completed by GH Curtis, also of University of California, Berkeley, who later would conduct the petrological analysis of Gifford's New Caledonian pottery as well (in Gifford 1951; Gifford and Shutler 1956). Reba W Benedict,

4 Some of Damour's work was known to GHF Ulrich, the first Professor of Geology at Otago University, New Zealand, but the reference he cites in a table provided to his colleague FB Chapman is to Damour's analysis of a Chinese jade object (Chapman 1891: 539).

5 Information from letters archived in the Bancroft Library, University of California, Berkeley. 
a geology student supervised by Curtis, carried out petrological analysis of Yapese pottery from Gifford's last expedition of 1956. The Yap monograph was published posthumously in 1959 (Gifford and Gifford 1959), and perhaps because of this Benedict's work rates only the merest mention (Gifford and Gifford 1959:184-185).

The early Melanesian characterisation work was later to inspire geologist Bill Dickinson in starting his 40-plus-year association with Pacific archaeological pottery analysis (summarised in Dickinson 2006). Dickinson recounted how he was engaged in geological research in Fiji in 1965, while his graduate anthropologist wife Peggy decided to study a modern pottery-making community there (Dickinson and Sykes 1965). He was introduced to Helen and Lawrence Birks, then digging at the Sigatoka Dune site, who were trying to find a way to establish if the Lapita pottery discovered there was local or exotic. They naturally asked if there were applicable geological techniques for doing so. Knowing from his wife's study that local potters added mineral temper to the clay constituents of the pottery they were making, Dickinson concluded that petrological analysis was the answer to their question. He was later able to establish a local source for the pottery (Dickinson 1971).

Richard Shutler Jr, the graduate student who had accompanied Gifford to New Caledonia in 1952, was serendipitously visiting the Bishop Museum in Honolulu when Dickinson dropped in on his way home from Fiji. Dickinson later reported that upon meeting him and hearing of his expertise, Shutler exclaimed 'where have you been all my life?' They immediately embarked upon a collaborative project on Pacific pottery characterisation through thin section analysis that continued until Shutler's death in $2007 .^{6}$

The initial summary publication of Dickinson's ceramic studies was in Yawata and Sinoto's edited volume from the 11th Pacific Science Congress held in Japan in 1966 (Dickinson and Shutler 1968), soon followed by his published specialist report in Green and Davidson's first volume on The Archaeology of Western Samoa (Dickinson 1969:271-273). ${ }^{7}$ This was some years after Curtis' pioneering work on the petrology of New Caledonian pottery, suggesting a significant time lag. But it must be noted that apart from $\mathrm{PhD}$ theses, there had been no monographic treatments of the archaeology of Pacific pottery-using areas in that interval, apart from Gifford's own alreadymentioned 1959 monograph, Alex Spoehr's work on Marianas Prehistory (1957) and Douglas Osborne's The Archaeology of the Palau Islands (1966). Spoehr did not include any petrological analysis, while Osborne had thin sections of pottery made and analysed by Dale Kramer of the University of Washington Geology Department, but made very little of them in the absence of detailed knowledge of regional geology. In this, Dickinson had the clear advantage and from the start was able to establish distinct temper regions within the broader Pacific (Dickinson and Shutler 1968).

As Gifford's Fiji monograph (1951), containing Curtis' petrological report, was the first to report substantive excavations in any area of the Pacific where pottery was in use, it can hardly be said of that that it represented a significant time lag after common use in the United States and elsewhere of petrographic analysis of ceramics.

Others, independently however, had also embarked upon petrographic analysis of Pacific ceramics in the 1960s, notably the pioneer archaeological scientist Con Key in Jack Golson's unit within the Anthropology and Sociology Department at ANU in Canberra. Hired for a five-year

\footnotetext{
6 The sources for the history of Bill Dickinson's involvement in pottery studies in the Pacific are from personal communications over a long period of time, particularly over dinner in San Francisco in April 2015, just a few months before his death on fieldwork in Tonga in July of that year, backed up by the account in the Preface to Dickinson's summary monograph (2006:vii).

7 Burley and Weisler (2016:83) note that the first of Dickinson's generally unpublished specialist reports, numbering 322 at his death, was dated 1966 and 'characterizes the temper of a Lapita sherd from Efate, Vanuatu'. His first published Fiji summary report is dated as submitted in 1968 (Dickinson 1971).
} 
fellowship in 1965, having been trained in geology in Holland and South Africa, Key initiated a number of innovative characterisation studies of both pottery and obsidian in his position as Research Fellow in Environmental Archaeology. The lack of a job after his fellowship finished meant he was lost to archaeology, going to work for the Western Australia Department of Main Roads; he died soon afterwards (Jack Golson, pers. comm. November 2017).

Key's petrological reports were at first appended to various $\mathrm{PhD}$ theses coming out of what became in May 1969 the Department of Prehistory in the Research School of Pacific Studies at ANU, led by Jack Golson. These started with a 1966 report for Jens Poulsen who was working on Tongan Lapita sites (later published in Poulsen 1987) and was followed by a 1967 report for J Peter White who was researching in the Eastern Highlands of Papua New Guinea (PNG, published in White 1972). Key carried out independent studies of ethnographic and some prehistoric pottery in the Massim area of PNG, establishing there had been exchange between the Collingwood Bay area and the Trobriands (Key 1968a). His other major work was on the sourcing of New Guinea obsidians using spectrographic analysis of trace elements (Key 1968b, 1969), showing that obsidian from the Lapita sites on Watom Island could be sourced to the Talasea area of West New Britain some $270 \mathrm{~km}$ away. This was the first archaeologically oriented study of Melanesian obsidians; they did not feature at all in Cann et al.'s (1969) world survey.

Spectrographic methods had first been developed near the beginning of the 19th century, but optical spectroscopy had been first applied to archaeological materials such as metals and faience beads in the 1950s (Britton and Richards 1969). The first publication on trace elements detected using optical spectroscopy for characterising obsidians was in 1964, starting a major study of Anatolian and other obsidian exchange in the Eastern Mediterranean and Middle East (Cann and Renfrew 1964). Roger Green and colleagues in New Zealand were quick on the uptake (Green et al. 1967), with Key's work being a further development of the technique.

Green had initially become interested in obsidian for its potential as a tool for dating, and as a visiting Fulbright Scholar had issued an appeal in the December 1958 issue of the New Zealand Archaeological Association Newsletter for samples (Scarlett 1958:3). He had read of the use of refractive index as a means of characterising obsidian (Boyer and Robinson 1955) and heard of the development of hydration dating from American researchers, who were later to publish their results (Clark 1961; Friedman et al. 1960). Working with Auckland geologist RN Brothers (an early collaborator of Jack Golson in Auckland in the mid-1950s), Green used general appearance and refractive index measurements in an attempt to characterise sources in New Zealand, as had earlier been applied with some success in the Southwest of the United States and in Japan (Green 1962). ${ }^{8}$ Working also with Wal Ambrose at Auckland, Green was quick to publish the first New Zealand obsidian hydration results (Ambrose and Green 1962). There was clearly no time lag in that particular application from its successful development and publication to a Pacific application. In 1964 Green published a further report on New Zealand obsidian sources and the dating of their use (Green 1964), and Green and colleagues' 1967 sourcing paper using emission spectroscopy was again, as we have seen, published within three years of the earliest published work anywhere on obsidian sourcing using this technique (Green et al. 1967).

Ambrose and Green teamed up again in 1972, using emission spectrography in the first paper to establish inter-archipelago movement of materials during the Lapita period, in this case obsidians from Talasea being transported some $2000 \mathrm{~km}$ to the outer eastern islands of the

8 And also in New Zealand: the earliest specifically petrological interest in archaeological obsidians in the Pacific seems to be that of Prof. DS Coombs of Otago University (see also footnote 11, below). Golson (1957a:285) refers to him reporting on a unique obsidian piece from Pounawea, South Island, New Zealand, that it had a refractive index and chemical constituents different from Mayor Island obsidian. This predates Green's New Zealand involvement in the subject. 
Solomons (Ambrose and Green 1972). Before this date it was scarcely possible to discuss Lapita exchange, although Key's work had shown the way; subsequently it has become a major topic of Lapita studies.

Ambrose had relocated to ANU in 1963, lured by Jack Golson's earlier move there from Auckland in 1961, and as a research officer had been a colleague of Key's. Ambrose's obsidian interests continued, and he soon became the major archaeological specialist on obsidian characterisation in the Pacific. Summerhayes et al. (1998, updated in Summerhayes 2009) provide a useful history of the successive techniques used to refine the sourcing of Pacific, mainly Melanesian, obsidians: X-ray fluorescence (XRF) was applied in 1974, neutron activation analysis (NAA) in 1976, but was quickly succeeded by proton-induced gamma emission analysis (PIGME) that same year (a technique developed only in 1972), to be combined with proton-induced X-ray emission analysis (PIXE) by 1979 as PIXE-PIGME, and finally with laser ablation inductively coupled plasma mass spectrometry (LA-ICP-MS) taking over as the technique of choice around 2008.

Other techniques have been used intermittently as well since the 1990s (Summerhayes 2009:110), most significantly portable XRF (pXRF). This technique allows the researcher to come to where the samples are, rather than the other way around, is non-destructive, relatively inexpensive and requires little specialised training to use, in contrast to many of the other available techniques. The aim of all this technique shifting has been to allow rapid characterisation of multiple samples and an ever more refined differentiation of subsamples within general source areas, while also being mindful of cost, of what equipment was available in any particular institution and of being able to gain the interest of those who were in charge of the equipment. Ambrose's name appears as one of the authors on papers on almost every new development in the field to the present.

Petrography of ceramics has been mentioned as having been a long-standing technique in Pacific archaeology, and thin section analysis of Pacific stone resources similarly did not lag far behind its use elsewhere. Histories of the use of petrology in the United Kingdom such as that by Grimes (1979) usually begin with reference to HH Thomas' (1923) study of the source of the Stonehenge bluestones, identified as coming from the Preseli Mountains of Wales. Thomas was the petrographer of the United Kingdom Geological Survey from 1911 to his untimely death in 1935 (Harker 1935). His earliest involvement with the sourcing of axes was reported in a paper on the Graig Lwyd axe quarry in 1919 (Warren 1919, 1921) and he continued to advise on axe petrology until his death (Keiller et al. 1941). His immediate successor as Geological Survey petrographer was James Phemister who also gets an honourable mention for his petrographic work on British stone axes in the 'First Report of the South-Western Group of Museums and Art Galleries on the Petrological Identification of Stone Axes', covering the period 1936 to 1941 (Keiller et al. 1941, and references therein).

In a discussion of seemingly exotic basaltic stone adzes found on the coast of New South Wales, Australia, and on Norfolk Island, WW Thorpe (1929), the ethnologist at the Australian Museum in Sydney, sought out the petrologist T Hodge Smith to examine thin sections of the specimens and a comparator from Great Barrier Island in New Zealand. Smith was unable to suggest a clear source for these adzes, noting only that 'similar basalts are very widely distributed in the Pacific regions' (quoted in Thorpe 1929:126).

In an 1891 paper, 'On the working of greenstone or nephrite by the Maoris', that does not otherwise include any scientific analysis of nephrite artefacts, there is appended a table provided by the Foundation Geology Professor at Otago University, GHF Ulrich (Chapman 1891:539), already referred to (see footnote 4). In addition to Damour's analysis of a Chinese jade, the table also included chemical analyses of New Zealand nephrites by Scheerer and Melchior and Meyer, but no sources are given. 
However, the earliest published petrology on New Zealand nephrite artefacts aimed at understanding provenance was published in 1935, based on an oral presentation of 1932 (Turner 1935). ${ }^{9}$ FJ Turner, a geologist at Otago University appointed in 1926, was inspired to undertake the study of 120 artefacts by ethnologist HD Skinner. Skinner maintained strong academic links with British archaeologists and would have heard of the work of Thomas in this field. At the time of publication of Turner's research, it was in fact the largest-scale study of its kind; the major United Kingdom study of Neolithic axe sourcing mentioned earlier did not get underway until the following year (Keiller et al. 1941). Turner's paper was not, however, as far as I can see, referenced in the United Kingdom for another 30 years (Clark 1965).

New Guinea petrographic analyses followed soon after in 1936 when Moyne and Haddon published a summary of thin section analyses of Mount Hagen and Aiome stone axes conducted by Phemister (Moyne and Haddon 1936:272). There had been earlier petrological interest in New Guinea adzes and axes, not least by Dr John E Marr and Mr WG Fearnsides of Cambridge University, who examined the products of the Suloga Quarry on Woodlark Island in the Massim and adzes from Collingwood Bay on the mainland for Seligmann around 1906 (Seligmann and Joyce 1907:331; Seligmann and Strong 1906:353-354; cf. Seligmann 1910:517). It is not clear, however, that Marr's examination extended beyond hand specimens. Similarly, Malinowski (1934:190) credits Dr EW Skeats, Professor of Geology at Melbourne University, for petrological examination of eastern New Guinea stone artefacts, but again gives no details of the actual analyses conducted.

Petrological thin section analysis seems to have been applied systematically only from the 1960s in the Pacific, in Melanesia at least as early as in the rest of the region. ${ }^{10}$ When Golson moved from Auckland to ANU in 1961, an early priority of his was the establishment of a petrological laboratory there for the analysis of stone and pottery artefacts (Golson 1962). Brookfield and Brown (1963:65) reported thin section analysis of five PNG Highlands adzes by WR Morgan of the Bureau of Mineral Resources in Canberra and by GA Joplin of ANU. The annus mirabilis for the technique seems to have been 1966: Chappell and Strathern (1966) on PNG Highlands material, Verhofstad (1966) on West Papuan Highlands adzes, and a 1966 report for Jens Poulsen's Tongan thesis on stone adzes from Tongatapu by AJR White of the Geology Department of ANU (published in Poulsen 1987).

Thin section analysis has not proved very popular in the study of Pacific adzes as it requires a slice or plug to be cut out of the adze (see Adam (1953:414 fn.) in relation to PNG Highlands specimens, for instance). Other minimal or non-destructive techniques were adopted later, most

9 Turner had earlier conducted a petrological analysis of a piece of greenstone, possibly an axe fragment, from Aitutaki in the Cook Islands. He sourced it to Milford Sound in New Zealand, noting that he had recently completed the paper which was eventually published in 1935 (quote by Skinner 1933:225-226). For a short history of the Otago Geology Department see www.otago.ac.nz/ geology/about/history.html.

10 Parker and Sheppard (1997) give primacy at Auckland University to Eleanor Crosby's (1963) alleged thin section analysis of New Zealand basalt artefacts, although this is a misattribution (Eleanor Crosby pers. comm. January 2019). They list the many contributions—not least John Chappell's— to adze geochemistry emanating from Auckland University, perhaps inspired at least in part by Roger Green's undergraduate background in geology. Chappell's original New Guinea petrological report, however, also dates to 1963, as reported by Susan Bulmer (1964b). Otago University can claim the earliest Pacific interest, as noted above. Turner's interest there was continued by his successor at Otago from 1947, Prof. DS Coombs of the Geology Department who used the 'X-ray powder method' on a small fragment of an argillite adze from Taranaki to source it tentatively to the Nelson district (Skinner 1953). Coombs gave a paper at the New Zealand Archaeological Association's 1957 second conference, on 'The use of petrology in delimiting the sources of the stone materials of the Moa hunters', based on thin section analysis of flakes from Leslie Lockerbie's excavation at Pounawea (summarised in Golson 1957a:271, 284-285; see also Lockerbie 1959). While Gifford thanks Prof. Howel Williams of University of California, Berkeley, for mineralogical identification of adzes and other stone from Fiji, New Caledonia and Yap, his analysis does not appear to have extended beyond examination of hand specimens (Gifford 1951:221; Gifford and Shutler 1956:68; Gifford and Gifford 1959:193-194). Firth (1959:153) reports on thin section characterisation of Tikopian (Solomon Islands) stone adzes carried out by Dr W Campbell Smith of the Department of Mineralogy, British Museum (Natural History), but with no comparative work undertaken to provenance them. 
recently pXRF because of its portability. The range of chemical characterisation techniques available has been deployed much more systematically in Polynesia than in Melanesia (see papers in Weisler 1997). It is fair to say that outside mainland New Guinea there has been much less interest in adze sourcing in Melanesia compared to the rest of the Pacific, despite the promising start in the mid-1960s and continued attention from Roger Green and his associates on the South-East Solomons Culture History Project (Green 1978; Kirch and Yen 1982:232-237; Leach and Davidson 2008; Moore 1978; Sheppard 1996) and in Fiji (Best 1989 [orig. 1984]). The aforementioned research on Polynesian Outliers and some other sites by Green and his associates turned up adzes of Samoan origin in later prehistoric contexts; apart from language these remain the only certain link between the Outliers and their presumed easterly Polynesian cultural source.

The deployment of these techniques for the characterisation and provenance of pottery and stone artefacts has largely created the study of prehistoric exchange. Until their deployment, all that could be done at best was recognition that certain materials were exotic to the place in which they were found, and an appeal in places such as the Pacific to ethnohistorically documented exchange systems as illustrating the kinds of social relations possibly entailed by the archaeological evidence.

\section{Practices and productivities: Manufacture, palaeoenvironments and the archaeology of death}

\section{Manufacture}

The chances to observe the making of stone artefacts, as opposed to sourcing where they may have come from, were taken up to some extent in Melanesia; almost solely, however, in New Guinea. The major opportunity was afforded by the fact that the relatively isolated Highlands region was not penetrated by Europeans until the 1930s, when only a few worn steel axes had reached there through traditional exchange routes with lowlands societies who had had access to metal since the previous century. Thus, Seligmann complained upon his visit to the Suloga Adze quarry on Woodlark Island in 1904 that the quarry had been abandoned for a generation and the adze makers had died out through introduced diseases (Seligmann and Strong 1906:350).

Missionaries and anthropologists were quick to get into the Highlands but generally were not much interested in technology and artefact production, although traditional exchange, including of stone adzes/axes, did gain their early attention. An exception was LG Vial (1940) who visited two stone quarries in 1938 and 1939 and provided a description and photographs of how they were worked. Clark (1965:19) complains of the general lack of attention by early visitors to the Highlands, and Chappell, who visited many of the adze quarries between 1963 and 1965, encountered only one man whom he considered a skilled maker of stone tools (Chappell and Strathern 1966:103, 105). John Burton, however, was able to conduct a detailed study of adze manufacture from the memory of men in the early 1980s who had been among the last generation to have seen the quarries in operation (Burton 1987). Stone adze/axe procurement and manufacture using traditional practices continued much longer in the Highlands of West Papua, and the Pétrequins were able to take movie film of axe makers and record in detail their techniques at various remote locations in the 1980s (Pétrequin and Pétrequin 1993).

For flaked stone the situation was somewhat better in the PNG Highlands and J Peter White was able to produce a detailed record of production techniques in the 1960s (1967, 1968; White et al. 1977), as was Maurice Godelier (Godelier with Garanger 1973). Traditional pottery making throughout Melanesia lasted much longer than stone artefact production; indeed in some areas it remains vibrant today and has been subject to many studies (for PNG see 
particularly May and Tuckson 1982). It died out early, however, in New Caledonia at the turn of the 20th century but was recorded in place by various savants (as summarised by Sarasin 2009 [orig. 1929]:116-119). Ways of working shell for tools and ornaments have also received sustained levels of attention over the years.

Understanding prehistoric technologies allows one to examine questions of craft specialisation and potential levels of production, and assess whether particular craft skills were easily acquired or would have required long apprenticeships.

\section{Palaeoenvironments and human impacts}

Ideas of environmental change and human impacts upon landscape during human occupation of the Pacific Islands were strongly taken up by scholars working in Melanesia, as elsewhere in the Pacific. The general influence came from what would now be called historical ecology, and Kirch (1997) has summarised its development, particularly from an American perspective. In Australia it was more the demonstration of human impacts on the environment by palynologists working in New Guinea from the beginning of the 1970s and the work of geomorphologists such as Philip Hughes (for instance Hughes et al. 1979) that were particularly influential. The papers in Kirch and Hunt (1997) that relate to Melanesia show these more immediate influences, rather than those that inform most of the Polynesian studies in that volume.

The Pacific featured very early in discussion of 'megafaunal' extinctions, with the first New Zealand reports of bones of extinct giant birds later to be known as 'moa' published in 1838, and the first palaeontological description of the bones in 1839 by the brilliant anatomist Richard Owen. Moa-hunting sites were described from 1843 onwards (see Anderson 1989 for references). The extent of bird extinctions from the rest of Polynesia, although none of the species was as large as the largest moas, only became fully apparent from the 1980s onwards (Steadman 2006).

New Guinea's megafauna were first described as potentially associated with human occupation in the 1970s at the site of Nombe (Mountain 1979; White and O'Connell 1982:91). Flannery's (1995) contention that the Pleistocene megafauna of New Guinea were 'almost entirely unknown' (1995:48) until his own publications from 1983 onwards is not completely accurate. He in fact provides references to significant earlier research, although he seems to have missed an archaeologically related study by Plane (1972). That there was a major advance in knowledge of the New Guinea megafauna in the 1980s is certainly true, however, not least through Flannery's own studies of the Nombe fauna and that from other locations (summarised in Flannery 1995:48-54).

New Caledonia's extinct birds and reptiles were first reported in detail during the decade of the 1980s by Balouet and his colleagues, initially from fossil sites yielding remains of large birds, land crocodiles and tortoises. Remains from archaeological as opposed to fossil sites were first reported by Balouet and Olson at the end of the decade (1989). Solomon Islands' large extinct rats were reported from Pleistocene through mid-Holocene occupation deposits from Buka soon afterwards (Flannery and Wickler 1990), while Vanuatu's extinct land crocodiles, tortoises and birds had to wait until the 21st century before they were reported from archaeological sites there (Mead et al. 2002; White et al. 2010; Worthy et al. 2015). Steadman (2006:111-159) presents a comprehensive overview of human-induced avian extinctions in Melanesia known to that time.

From the above it can be seen that with the notable exception of New Zealand, where the ubiquitous bones of various moa species were hard to ignore, it would have been impossible to discuss the major human role in Pacific vertebrate extinctions until after 1980; before then there were precious few palaeontological and archaeozoological data on which to hang a story. A whole bestiary of fauna has since been revealed, evidence of some of the 'pull' factors that may 
have encouraged early exploration and settlement. Sadly, it also documents the major humaninduced impacts on a 'naïve' fauna, that in some cases would have included 'keystone' species vital to the environmental balance on islands (Kirch 2017:229-231). Once that fragile balance was upset, environmental degradation was inevitable on small, and often otherwise depauperate island groups.

\section{The archaeology of death}

Funerary archaeology in the Pacific has a long history, with some major early excavations in Hawaii and New Zealand (Kirch 2017). In Melanesia it has been most spectacularly investigated at the Roi Mata burial site on Eretoka or Hat Island off the coast of Efate, now part of the World Heritage Site of Chief Roi Mata's Domain. Garanger's excavation of a mass chiefly grave there, linked to oral traditions, was published in 1972, along with other graves associated with detailed traditions also excavated by him on Tongoa Island in the same period (Garanger 1972). Central Vanuatu is also the location of the largest Lapita-phase cemetery recorded, at Teouma on Efate itself, excavated between 2004 and 2010 (Bedford et al. 2006, 2010). It was at this site that the innovative French forensic approach, infelicitously labelled anthropologie de terrain was first applied in the Pacific (Valentin et al. 2010a). Until the excavation of Teouma, this major strand of Lapita archaeology was virtually unknown, hindering discussion of important questions about Lapita ritual and of comparison with the comparatively rich Island South-East Asian funerary record from sites like Niah, and various Taiwanese Neolithic sites (Bellwood 2017).

The SAC site on Watom, off the coast of New Britain (Petchey et al. 2016 and references therein), and the Sigatoka Dune Site on Viti Levu in Fiji (Marshall et al. 2000) are the only other major Lapita and immediately post-Lapita open funerary sites in Melanesia where information on funerary practice has been published from more than a handful of burials. At the Watom site, as at Teouma, a range of isotopic and skeletal pathology studies have also been carried out (see Petchey et al. 2016 for the most recent summary of work there). Also of note is a large series of second millennium CE burials investigated on the Polynesian Outlier island of Taumako in the Solomons (Leach and Davidson 2008:133-253; see also Buckley 2001; Kinaston and Buckley 2017). Apart from this, there is a long history of Melanesian funerary studies of cave burials, some placed inside pottery vessels, going back to the early decades of the 20th century in the archaeological literature (see for instance Austen 1939; Lyons 1922; Seligmann 1910:731).

Before the recent discovery and scientific analysis of Lapita and later cemetery data in Melanesia, there were whole areas of ritual and symbolic life, and of the health and genetic affinities of early Pacific populations that were inaccessible to archaeologists. For example, we can now examine the human health 'costs' of colonisation of previously uninhabited island groups (Buckley et al. 2008, 2014; Foster et al. 2018), aspects of Lapita diet breadth (Kinaston et al. 2014; Valentin et al. 2010b) and changes in both through time (Valentin et al. 2014).

\section{Concluding discussion}

As can be seen from the examples given above, scientific applications and practices developed in America and Europe have generally been very quickly taken up in the Pacific, including in Melanesia. No significant lags can be identified between their development and general use in the metropoles and in our region. This can be explained by the fact that there was never an isolated development of archaeological practice in the Pacific. It was a European and American transplant, at first of interest to museum and, to a lesser extent, university scholars. All of these had access in their institutions or through international networks to a range of expertise beyond 
their own disciplines, initially calling upon geologists and biologists and later upon chemists and nuclear physicists. The widespread exchange of publications between museums and learned societies worldwide played a not insignificant role in such rapid dissemination.

Pacific archaeologists were among the first to recognise the immense promise of radiocarbon dating, and a radiocarbon dating laboratory was established in New Zealand within a couple of years of the availability of this revolutionary technique to archaeologists anywhere in the world. Characterisation and provenance studies of Pacific stone axes/adzes using thin section petrology were in use within a decade or so of their regular deployment in the United Kingdom, and other techniques of sourcing pottery and stone were also rapidly taken up in the region. This is particularly true of developments in obsidian characterisation, where deployment in New Zealand was almost simultaneous with the announcement of the first results in Anatolia and the Eastern Mediterranean.

Broader-scale practices such as the development of settlement pattern studies and landscape archaeology, backed by the use of aerial photographic analysis, were also deployed in a timely manner in the Pacific and Melanesia. Developments in both British and American traditions in these areas were quickly disseminated, as were the somewhat separate but complementary approaches used in palaeoenvironmental reconstruction and a consciousness of the role of human impacts in shaping Pacific environments. The latest developments in funerary archaeology as well, particularly the forensic techniques of anthropologie de terrain, have also been eagerly adopted in Melanesia. LiDAR surveys, which will further revolutionise our knowledge of settlement patterns in the region, are also now starting to become widely available.

Entire topics of study that are now considered central to archaeological practice could barely be considered before the development of some of the techniques listed above. Before radiocarbon dating in the 1950s there was no chronological framework available in the Pacific for periods before European contact apart from genealogically-linked oral traditions. These could only be used to go back a few hundred years in most cases. The archaeological study of exchange systems could not go beyond the ethnohistorical record and ethnographic analogy until artefact petrology and later characterisation techniques could be brought to bear on the problem. The impoverished biogeography of the Pacific at European contact was not recognised, beyond the question of the New Zealand moas, until palaeontological and archaeozoological research from the 1980s onwards revealed the past diversity of species, and the terrible effects that human settlement of the Pacific Islands had upon them.

The characterisation of phases or stages of Pacific archaeology often privileges developments in theory, the professionalisation of archaeology in the post-World War II period or the deployment of 'scientific' excavation techniques to key sites. These are all important markers for the history of the discipline in the Pacific that we attempt to understand. Knowing about the availability and procurement of particular archaeological science practices and techniques provides the possibility of other ways of organising disciplinary history that allow us to understand what it was possible to know at any particular moment about the region's past.

\section{Acknowledgements}

The Collective Biography of Archaeology in the Pacific (CBAP) project is funded by the Australian Research Council (ARC) as grant FL140100218 and by ANU. Thanks to my CBAP colleagues for discussions and to Catherine Fitzgerald for administrative support. Particularly fruitful discussions in relation to the paper have been had with Wal Ambrose, Stuart Bedford, Dave Burley, the late Bill Dickinson, Jack Golson and the volume editors. Wal Ambrose also provided 
some vital published and unpublished sources. The paper was finished at the Vila Rose Hotel, Port Vila, Vanuatu and, as ever, the extreme patience of Rosemary Leona during its production is gratefully acknowledged.

\section{References}

Adam, L. 1953. 'The discovery of the Vierkantbeil or quadrangular adze head in the Eastern Central Highlands of New Guinea'. Mankind 4:411-423.

Allen, J and C Gosden (eds). 1991. Report of the Lapita Homeland Project. Occasional Papers in Prehistory 20. Canberra: Department of Prehistory, Research School of Pacific Studies, The Australian National University.

Ambrose, W and R Green. 1962. 'Obsidian dating: Preliminary results'. New Zealand Archaeological Association Newsletter 5:247-248.

Ambrose, W and R Green. 1972. 'First millennium BC transport of obsidian from New Britain to the Solomon Islands'. Nature 237:31. doi.org/10.1038/237031a0.

Anderson, A. 1989. Prodigious birds: Moas and moa-hunting in prehistoric New Zealand. Cambridge: Cambridge University Press.

Austen, L. 1939. 'Megalithic structures in the Trobriand Islands'. Oceania 10 (1):30-53. doi.org/ 10.1002/j.1834-4461.1939.tb00255.x.

Ballard, C. 1994. 'The centre cannot hold: Trade networks and sacred geography in the Papua New Guinea Highlands'. Archaeology in Oceania 29:130-148. doi.org/10.1002/arco.1994.29.3.130.

Balouet, JC and S Olson. 1989. Fossil birds from late Quaternary deposits in New Caledonia. Smithsonian Contributions to Zoology 469. Washington, DC: Smithsonian Institution Press.

Barnes, I. 2003. 'Aerial remote-sensing techniques used in the management of archaeological monuments on the British Army's Salisbury Plain Training Area, Wiltshire, UK'. Archaeological Prospection 10:83-90. doi.org/10.1002/arp.197.

Bedford, S and M Spriggs. 2008. 'Northern Vanuatu as a Pacific crossroads: The archaeology of discovery, interaction and the emergence of the "ethnographic present"'. Asian Perspectives 47 (1):95-120.

Bedford, S, M Spriggs and R Regenvanu. 2006. 'The Teouma Lapita Site and the early human settlement of the Pacific Islands'. Antiquity 80:812-828. doi.org/10.1017/S0003598X00094448.

Bedford, S, M Spriggs, H Buckley, F Valentin, R Regenvanu and M Abong. 2010. 'A cemetery of first settlement: Teouma, South Efate, Vanuatu/ Un cimetière de premier peuplement: le site de Teouma, sud d'Efate'. In Lapita: Ancêtres Océaniens / Oceanic ancestors, edited by C Sand and S Bedford, 140-161. Paris: Musée de Quai Branly and Somogy Éditions d'Art.

Bedford, S, P Siméoni and V Lebot. 2018. 'The anthropogenic transformation of an island landscape: Evidence for agricultural development revealed by LiDAR on the island of Efate, Central Vanuatu, South-West Pacific'. Archaeology in Oceania 53 (1):1-14. doi.org/10.1002/arco.5137.

Bellwood, P. 2017. First islanders: Prehistory and human migration in Island Southeast Asia. Hoboken, NJ: Wiley Blackwell. doi.org/10.1002/9781119251583.

Best, S. 1989 [orig. 1984]. Lakeba: The prehistory of a Fijian island. Ann Arbor, Michigan: University Microfilms.

Bewley, R. 2003. 'Aerial survey for archaeology'. Photogrammetric Record 18 (104):273-292. doi.org/ 10.1046/j.0031-868X.2003.00023.x. 
Bewley, R, S Crutchley and C Shell. 2005. 'New light on an ancient landscape: LiDAR survey in the Stonehenge World Heritage Site'. Antiquity 79 (305):636-647. doi.org/10.1017/ S0003598X00114577.

Blake-Palmer, G. 1947. 'New Zealand archaeology and air photography'. Journal of the Polynesian Society $56(3): 233-241$.

Bonnemaison, J. 1974. 'Espaces et paysages agraires des Nouvelles-Hébrides'. Journal de la Société des Océanistes 44-45:163-232, 259-281.

Bonnemaison, J. 1979. 'Les voyages et L'enracinement: Formes de fixation et de mobilité dans les sociétés traditionelles des Nouvelles-Hébrides'. L'Espace Géographique 4:303-318. doi.org/10.3406/ spgeo.1979.1937.

Boyer, WW and P Robinson. 1955. 'Obsidian artifacts of Northwestern New Mexico and their correlation with source material'. El Palacio 63:333-345.

Britton, D and E Richards. 1969. 'Optical emission spectroscopy and the study of metallurgy in the European Bronze Age'. In Science in Archaeology, edited by D Brothwell and E Higgs, 2nd edn, 603-613. London: Thames and Hudson.

Brookfield, H and P Brown. 1963. Struggle for land: Agriculture and group territories among the Chimbu of the New Guinea Highlands. Melbourne: Oxford University Press.

Brookfield, H and D Hart. 1971. Melanesia: A Geographical Interpretation of an Island World. London: Methuen.

Buckley, H. 2001. 'Health and disease in the prehistoric Pacific Islands'. Unpublished PhD thesis, Otago University, Dunedin.

Buckley, H, N Tayles, M Spriggs and S Bedford. 2008. 'A preliminary report on health and disease in Early Lapita skeletons, Vanuatu: Possible biological costs of island colonization'. Journal of Island and Coastal Archaeology 3 (1):87-114. doi.org/10.1080/15564890801928300.

Buckley, H, R Kinaston, S Halcrow, A Foster, M Spriggs and S Bedford. 2014. 'Scurvy in a tropical paradise? Evaluating the possibility of infant and adult Vitamin C deficiency in the Lapita skeletal sample of Teouma, Vanuatu, Pacific Islands'. International Journal of Paleopathology 5:72-85. doi.org/10.1016/j.ijpp.2014.03.001.

Bulmer, S. 1964a. 'Radiocarbon dates from New Guinea'. Journal of the Polynesian Society 73:327-328.

Bulmer, S. 1964b. 'Prehistoric stone implements from the New Guinea Highlands'. Oceania 34 (4):246268. doi.org/10.1002/j.1834-4461.1964.tb00268.x.

Burley, D and M Weisler. 2016. 'William R. Dickinson: Our appreciation of an archaeologist's geologist'. Archaeology in Oceania 51 (2):81-83. doi.org/10.1002/arco.5092.

Burton, J. 1987. Axe makers of the Wahgi: Pre-colonial industrialists of the Papua New Guinea Highlands. Ann Arbor, Michigan: University Microfilms.

Cann, J and C Renfrew. 1964. 'The characterization of obsidian and its application to the Mediterranean Region'. Proceedings of the Prehistoric Society 30:111-133. doi.org/10.1017/S0079497X00015097.

Cann, J, J Dixon and C Renfrew. 1969. 'Obsidian analysis and the obsidian trade'. In Science in Archaeology, edited by D Brothwell and E Higgs, 2nd edn, 578-591. London: Thames and Hudson.

Chang, K-C. 1958. 'Study of the Neolithic social grouping: Examples from the New World'. American Anthropologist 60:298-334. doi.org/10.1525/aa.1958.60.2.02a00080.

Chang, K-C. 1972. Settlement Patterns in Archaeology. Reading, Mass.: Addison-Wesley Publishing. 
Chapman, F. 1891. 'On the working of greenstone or nephrite by the Maoris'. Transactions of the New Zealand Institute 24:479-539.

Chappell, J and M Strathern. 1966. 'Stone axe factories in the Highlands of East New Guinea, with a note on linguistic boundaries and the axe quarries'. Proceedings of the Prehistoric Society 32:96-121. doi.org/10.1017/S0079497X00014365.

Chappell, J, A Omura, M McCulloch, T Esat, Y Ota and J Pandolfi. 1994. 'Revised late Quaternary sea levels between 70 and $30 \mathrm{Ka}$ from coral terraces at Huon Peninsula'. In Study on Coral Reef Terraces of the Huon Peninsula, Papua New Guinea: Establishment of Quaternary Sea Level and Tectonic History, edited by Y Ota, 155-165. Yokohama: Department of Geography, Yokohama National University.

Chase, A, D Chase, C Fisher, S Leisz and J Weishampel. 2012. 'Geospatial revolution and remote sensing LiDAR in Mesoamerican archaeology'. Proceedings of the National Academy of Sciences 109 (32):12916-12921. doi.org/10.1073/pnas.1205198109.

Clark, D. 1961. 'The obsidian dating method'. Current Anthropology 2(2):111-114. doi.org/10.1086/ 200172.

Clark, G. 1965. 'Traffic in stone axe and adze blades'. Essays in Economic History Presented to Professor M.M. Postan. The Economic History Review (new series) 18 (1):1-28. doi.org/10.2307/2591871.

Clarke, D. 1973. 'Archaeology: The loss of innocence'. Antiquity 47:6-18. doi.org/10.1017/ S0003598X0003461X.

Clarkson, C [and 27 others]. 2017. 'Human occupation of Northern Australia by 65,000 years ago'. Nature 547:306-310. doi.org/10.1038/nature22968.

Crane, HR. 1956. 'University of Michigan radiocarbon dates 1'. Science 124 (3324):664-672. doi.org/10.1126/science.124.3224.664.

Crawford, OGS. 1928. Air survey and archaeology. London: HMSO.

Crawford, OGS. 1953. Archaeology in the field. London: Phoenix House.

Crosby, E. 1963. 'Preliminary report on Whiritoa'. New Zealand Archaeological Association Newsletter 6:46-49.

Damour, A. 1865. 'Sur la composition des haches en pierre trouvées dans les monuments Celtiques et chez les tribus sauvages'. Comptes Rendus Hebdomadaires des Séances de l'Académie des Sciences 60:313-321, 61:357-368.

Daniel, G. 1975. A hundred and fifty years of Archaeology. 2nd edn. London: Duckworth.

Devereux, B, G Amable, P Crow and A Cliff. 2005. 'The potential of airborne lidar for detection of archaeological features under woodland canopies'. Antiquity 79 (305):648-660. doi.org/10.1017/ S0003598X00114589.

Dickinson, P and M Sykes. 1965. 'Kuro manufacture in Yavulo Village'. Records of the Fiji Museum $1(1): 69-72$.

Dickinson, WR. 1969. 'Temper sands in prehistoric potsherds from Vailele and Falefa'. In Archaeology in Western Samoa, Volume 1, edited by R Green and J Davidson, 271-273. Auckland Institute and Museum Bulletin 6. Auckland: Auckland Institute and Museum.

Dickinson, W. 1971. 'Petrography of some temper sands in prehistoric pottery from Viti Levu, Fiji'. Records of the Fiji Museum 1 (5):107-121. 
Dickinson, W. 2006. Temper sands in prehistoric Oceanian pottery: Geotectonics, sedimentology, petrography, provenance. The Geological Society of America Special Paper 406. Boulder, Colorado: The Geological Society of America.

Dickinson, WR and R Shutler Jr. 1968. 'Insular sand tempers of prehistoric pottery from the Southwest Pacific'. In Prehistoric culture in Oceania, edited by I Yawata and Y Sinoto, 29-37. Honolulu: Bishop Museum Press.

Evans, D, R Fletcher, C Pottier, J-B Chevance, D Soutif, BS Tan, S Im, D Ea, T Tin, S Kim, C Cromarty, S de Greef, K Hanus, P Baty, R Kuszinger, I Shimoda and G Boornazian. 2014. 'Uncovering archaeological landscapes at Angkor using LiDAR'. Proceedings of the National Academy of Sciences 110 (31):12595-12600.

Firth, R. 1959. 'Ritual adzes in Tikopia'. In Anthropology in the South Seas: Essays Presented to H.D. Skinner, edited by JD Freeman and WR Geddes, 149-159. New Plymouth, NZ: Thomas Avery and Sons.

Flannery, T. 1995. Mammals of New Guinea. Revised and updated edition. Chatswood, NSW: Reed Books.

Flannery, T and S Wickler. 1990. 'Quaternary murids (Rodentia: Muridae) from Buka Island, Papua New Guinea, with descriptions of two new species'. Australian Mammalogy 13:127-139.

Foster, A, R Kinaston, M Spriggs, S Bedford, A Gray and H Buckley. 2018. 'Possible diffuse idiopathic skeletal hyperostosis (DISH) in a 3000-year-old Pacific Island skeletal assemblage'. Journal of Archaeological Science: Reports 18:408-419. doi.org/10.1016/j.jasrep.2018.01.002.

Fox, C. 1923. The archaeology of the Cambridge region: A topographical study of the Bronze, Early Iron, Roman and Anglo-Saxon Ages, with an introductory note on the Neolithic Age. Cambridge: Cambridge University Press.

Freeland, T, B Heung, D Burley, G Clark and A Knudby. 2016. 'Automated feature extraction for prospection and analysis of monumental earthworks from aerial LiDAR in the Kingdom of Tonga'. Journal of Archaeological Science 69:64-74. doi.org/10.1016/j.jas.2016.04.011.

Friedman, I, R Smith, C Evans and B Meggers. 1960. 'A new dating method using obsidian'. American Antiquity 25:476-537. doi.org/10.2307/276634.

Garanger, J. 1972. Archéologie des Nouvelles-Hébrides: Contribution à la connaissance des îles du Centre. Publications de la Société des Océanistes 30. Paris: Société des Océanistes, Musée de l'Homme. doi.org/10.4000/books.sdo.859.

Gifford, E. 1951. Archaeological Excavations in Fiji. Anthropological records 13(3). Berkeley and Los Angeles: University of California Press.

Gifford, E. 1952. 'A carbon-14 date from Fiji'. Journal of the Polynesian Society 61:237.

Gifford, E. 1955. 'Six Fijian radiocarbon dates'. Journal of the Polynesian Society 64:240.

Gifford, E and D Gifford. 1959. Archaeological excavations in Yap. Anthropological Records 18(2). Berkeley and Los Angeles: University of California Press.

Gifford, E and R Shutler Jr. 1956. Archaeological excavations in New Caledonia. Anthropological Records 18(1). Berkeley and Los Angeles: University of California Press.

Godelier, M with J Garanger. 1973. 'Outils de pierre, outils d'acier chez les Baruya de Nouvelle-Guinée: Quelques données ethnographiques et quantitatives'. L'Homme 13:187-220. doi.org/10.3406/ hom.1973.367374.

Golson, J. 1957a. 'New Zealand archaeology, 1957'. Journal of the Polynesian Society 66(3):271-290. 
Golson, J. 1957b. 'Field archaeology in New Zealand'. Journal of the Polynesian Society 66(1):64-109.

Golson, J. 1962. 'Submissions on the development of prehistory at The Australian National University, Canberra. Submitted to the Universities Commission 1962'. Unpublished typescript in possession of the author. ANU, Canberra.

Golson, J. 1986. 'Old guards and new waves: Reflections on Antipodean archaeology, 1954-1975'. Archaeology in Oceania 21 (1):2-12. doi.org/10.1002/j.1834-4453.1986.tb00120.x.

Golson, J and R Green. 1959. A handbook to archaeological field recording in New Zealand. NZAA Handbook 1. Auckland: New Zealand Archaeological Association.

Gosden, C and C Pavlides. 1994. 'Are islands insular? Landscape vs. seascape in the case of the Arawe Islands, Papua New Guinea'. Archaeology in Oceania 29:162-171. doi.org/10.1002/ $\operatorname{arco.1994.29.3.162.~}$

Green, JH, J Harris, JWG Neuhaus, DKB Sewell and M Watson. 1965. 'University of New South Wales radiocarbon dates I'. Radiocarbon 7:162-165. doi.org/10.1017/S0033822200037140.

Green, R. 1962. 'Obsidian, its application to archaeology'. New Zealand Archaeological Association Newsletter 5:8-16.

Green, R. 1964. 'Sources, ages and exploitation of New Zealand obsidian: An interim report'. New Zealand Archaeological Association Newsletter 7:134-143.

Green, R. 1978. 'Notes on adze flakes, oven stones, pumice, muscovite-garnet schist and metamorphosed sandstone specimens from the main Reef/Santa Cruz Lapita Sites, Southeast Solomons'. Oceanic Prehistory Records 7:29-35. Microfiche. Auckland: University of Auckland Archaeological Society.

Green, R, R Brooks and R Reeves. 1967. 'Characterisation of New Zealand obsidians by emission spectroscopy'. New Zealand Journal of Science 10:675-682.

Grimes, W. 1979. 'The history of implement petrology in Britain'. In Stone axe studies, edited by TMcK Clough and W Cummins, 1-4. CBA Research Report 23. London: Council for British Archaeology.

Groube, L. 1965. Settlement patterns in New Zealand. Occasional Papers in Archaeology 1. Dunedin: Department of Anthropology, University of Otago.

Groube, L, J Chappell, J Muke and D Price. 1986. 'A 40,000 year-old human occupation site at Huon Peninsula, Papua New Guinea'. Nature 324:453-455. doi.org/10.1038/324453a0.

Harker, A. 1935. 'Herbert Henry Thomas 1876-1935'. Obituary Notices of Fellows of the Royal Society 1 (4):590-594.

Heine-Geldern, R. 1932. 'Urheimat und Früheste Wanderungen der Austronesier'. Anthropos 27:543-619.

Hughes, P, G Hope and M Latham. 1979. 'Prehistoric man-induced degradation of the Lakeba landscape: Evidence from two inland swamps'. In Lakeba: Environmental change, population dynamics and resource use, edited by $\mathrm{H}$ Brookfield, 93-110. UNESCO/UNFPA Population and Environment Project in the Eastern Outer Islands of Fiji, Island Reports 5. Canberra: UNESCO.

Keiller, A, S Piggott and F Wallis. 1941. 'First report of the sub-committee of the South-Western Group of Museums and Art Galleries on the petrological identification of stone axes'. Proceedings of the Prehistoric Society 7:50-72. doi.org/10.1017/S0079497X00020272.

Key, C. 1968a. 'Pottery manufacture in the Wanigela area of Collingwood Bay, Papua'. Mankind 6 (12):653-657. doi.org/10.1111/j.1835-9310.1968.tb00758.x.

Key, C. 1968b. 'Trace element identification of the source of obsidian in an archaeological site in New Guinea'. Nature 219:360. doi.org/10.1038/219360a0. 
Key, C. 1969. 'The identification of New Guinea obsidians'. Archaeology and Physical Anthropology in Oceania 4:47-55.

Kidder, A and A Shepard. 1936. The pottery of Pecos, Volume 2. Papers of the Southwestern Expedition 7. New Haven: Yale University Press.

Kinaston, R and H Buckley. 2017. 'Isotopic insights into diet and health at the site of Namu, Taumako Island, Southeast Solomon Islands'. Archaeological and Anthropological Sciences 9 (7):1421-1437. doi.org/10.1007/s12520-016-0440-y.

Kinaston, R, HR Buckley, F Valentin, S Bedford, M Spriggs, S Hawkins and E Herrscher. 2014. 'Lapita diet in Remote Oceania: New stable isotope evidence from the 3000-year-old Teouma Site, Efate Island, Vanuatu'. PLoS ONE 9 (3):e90376. doi.org/10.1371/journal.pone.0090376.

Kirch, P. 1985. Feathered gods and fishhooks: An introduction to Hawaiian archaeology and prehistory. Honolulu: University of Hawai'i Press.

Kirch, P. 1997. 'Introduction: The environmental history of Oceanic islands'. In Historical ecology in the Pacific Islands: Prehistoric environmental and landscape change, edited by P Kirch and T Hunt, 1-21. New Haven and London: Yale University Press. doi.org/10.2307/j.ctt211qz1v.6.

Kirch, P. 2017. On the road of the winds: An archaeological history of the Pacific Islands before European contact. Revised and expanded edition. Oakland: University of California Press.

Kirch, P and T Hunt (eds). 1997. Historical ecology in the Pacific Islands: Prehistoric environmental and landscape change. New Haven and London: Yale University Press. doi.org/10.2307/j.ctt211qz1v.6.

Kirch, P and D Yen. 1982. Tikopia: The prehistory and ecology of a Polynesian outlier. B.P. Bishop Museum Bulletin 238. Honolulu: Bishop Museum Press.

Ladefoged, T, M McCoy, G Asner, P Kirch, C Puleston, O Chadwick and P Vitousek. 2011. 'Agricultural potential and actualized development in Hawai' $\mathrm{i}$ : An airborne LiDAR survey of the leeward Kohala field system (Hawai'i Island)'. Journal of Archaeological Science 38 (12):3605-3619. doi.org/10.1016/j.jas.2011.08.031.

Leach, F and J Davidson. 2008. The archaeology of Taumako: A Polynesian outlier in the Eastern Solomon Islands. New Zealand Journal of Archaeology Special Publication. Dunedin: New Zealand Journal of Archaeology.

Libby, W. 1951. 'Radiocarbon dates, II'. Science 114 (2960):291-296. doi.org/10.1126/ science.114.2960.291.

Lockerbie, L. 1959. 'From moa-hunter to classic Maori in southern New Zealand'. In Anthropology in the south seas: Essays presented to H.D. Skinner, edited by JD Freeman and WR Geddes, 75-110. New Plymouth, NZ: Thomas Avery and Sons.

Lyons, AP. 1922. 'Sepulchral pottery of Murua, Papua'. Man 22 (Article 93):164-165.

Malinowski, B. 1934. 'Stone implements in Eastern New Guinea'. In Essays presented to C.G. Seligman, edited by E Evans-Pritchard, R Firth, B Malinowski and I Schapera, 189-196. London: Kegan Paul, Trench, Trubner \& Co.

Marshall, Y, A Crosby, S Mataraba and S Wood. 2000. Sigatoka: The shifting sands of prehistory. Oxford: Oxbow Books.

Matson, F. 1969. 'Some aspects of ceramic technology'. In Science in archaeology, edited by D Brothwell and E Higgs, 2nd edn, 90-602. Thames and Hudson, London.

May, P and M Tuckson. 1982. The traditional pottery of Papua New Guinea. Bay Books, Sydney. 
McCoy, M, G Asner and M Graves. 2011. 'Airborne lidar survey of irrigated agricultural landscapes: An application of the slope contrast method'. Journal of Archaeological Science 38 (9):2141-2154. doi.org/10.1016/j.jas.2011.02.033.

Mead, J, D Steadman, S Bedford, C Bell and M Spriggs. 2002. 'New extinct Mekosuchine crocodile from Vanuatu, South Pacific'. Copeia 2002 (3):632-641. doi.org/10.1643/0045-8511(2002)002 [0632:NEMCFV]2.0.CO;2.

Moore, P. 1978. 'Petrography of adzes from the Southeast Solomons'. Oceanic Prehistory Records 7:8-28. Microfiche. Auckland: University of Auckland Archaeological Society.

Mountain, MJ. 1979. 'The rescue of the ancestors in Papua New Guinea'. Institute of Archaeology, University of London, Bulletin 16:63-80.

Moyne, Lord and K Haddon. 1936. 'The pygmies of the Aiome Mountains, Mandated Territory of New Guinea'. Journal of the Royal Anthropological Institute 66:269-290.

Mulvaney, DJ. 1993. 'From Cambridge to the bush'. In A community of culture: The people and prehistory of the Pacific, edited by M Spriggs, D Yen, W Ambrose, R Jones, A Thorne and A Andrews, 18-26. Occasional Papers in Prehistory 21. Canberra: Department of Prehistory, Research School of Pacific Studies, The Australian National University.

Mulvaney, DJ. 2011. Digging up a past. Sydney: UNSW Press.

Osborne, D. 1966. The archaeology of the Palau Islands: An intensive survey. B.P. Bishop Museum Bulletin 230. Honolulu: Bishop Museum Press.

Parker, R and P Sheppard. 1997. 'Pacific Island adze geochemistry studies at the University of Auckland'. In Prehistoric long-distance interaction in Oceania: An interdisciplinary approach, edited by M Weisler, 205-211. NZAA Monograph 21. Auckland: New Zealand Archaeological Association.

Parry, J. 1977. Ring-ditch fortifications in the Rewa Delta: Air photo interpretation and analysis. Bulletin of the Fiji Museum 7.

Parry, J. 1997. The north coast of Viti Levu, Ba to Ra: Air photo archaeology and ethnohistory. Bulletin of the Fiji Museum 10.

Parsons, J. 1972. 'Archaeological settlement patterns'. Annual Review of Anthropology 1:127-150. doi.org/10.1146/annurev.an.01.100172.001015.

Petchey, P, H Buckley, R Walter, D Anson and R Kinaston. 2016. 'The 2008-2009 excavations at the SAC Locality, Reber-Rakival Lapita Site, Watom Island, Papua New Guinea'. Journal of Indo-Pacific Archaeology 40:12-31. doi.org/10.7152/jipa.v40i0.14928.

Pétrequin, P and A-M Pétrequin. 1993. Ecologie d'un outil: La hache de pierre en Irian Jaya (Indonésie). Monographe du CRA 12. Paris: CNRS Editions.

Phillips, C and M Campbell. 2004. 'From settlement patterns to interdisciplinary landscapes in New Zealand'. In Change through time: 50 years of New Zealand archaeology, edited by L Furey and S Holdaway, 85-104. NZAA Monograph 26. Auckland: New Zealand Archaeological Association.

Plane, M. 1972. 'Fauna from the basal clay of Kafiavana'. In Ol Tumbuna: Archaeological excavations in the eastern Central Highlands, Papua New Guinea, edited by JP White, 168. Terra Australis 2. Canberra: Department of Prehistory, Research School of Pacific Studies, The Australian National University.

Poulsen, J. 1987. Early Tongan prehistory, Volume 1. Terra Australis 12. Canberra: Department of Prehistory, Research School of Pacific Studies, The Australian National University. 
Quintus, S, J Clark, S Day and D Schwert. 2015. 'Investigating regional patterning in archaeological remains by pairing extensive survey with a lidar dataset: The case of the Manu'a Group, American Samoa'. Journal of Archaeological Science: Reports 2:677-687. doi.org/10.1016/j.jasrep.2014.11.010.

Rae, ID. 2018. 'Radiocarbon dating at the Museum of Applied Science Victoria 1952-70: A pioneer venture'. Historical Records of Australian Science 29:14-27. doi.org/10.1071/HR17019.

Reimer, P [and 27 others]. 2009. 'Intcal09 and Marine09 radiocarbon age calibration curves, 0-50,000 years cal BP'. Radiocarbon 51 (4):1111-1150. doi.org/10.1017/S0033822200034202.

Riesenfeld, A. 1952. 'Was there a Palaeolithic period in Melanesia?' Anthropos 47:405-446.

Roberts, R, R Jones and M Smith. 1990. 'Thermoluminescence dating of a 50,000-year-old human occupation site in Northern Australia'. Nature 345:153-156. doi.org/10.1038/345153a0.

Roberts, R, R Jones and M Smith. 1993. 'Optical dating at Deaf Adder Gorge, Northern Territory, indicates human occupation back to between 53,000 and 60,0000 years ago'. Australian Archaeology 37:58-59. doi.org/10.1080/03122417.1993.11681497.

Roux, J. 1990. 'Traditional Melanesian agriculture in New Caledonia and pre-contact population distribution'. In Pacific production systems: Approaches to economic prehistory, edited by D Yen and J Mummery, 161-173. Occasional Papers in Prehistory 18. Canberra: Department of Prehistory, Research School of Pacific Studies, The Australian National University.

Santayana, G. 1905. The life of reason, volume 1: Reason in commonsense. New York: Charles Scribner.

Sarasin, F. 2009 [orig. 1929]. Ethnographie des Kanak de Nouvelle-Calédonie et des Iles Loyauté. Paris: Ibis Press [Originally published as Ethnologie der Neu-Kaledonier und Loyalty-Insulaner. Munich: C.W. Kreidel's Verlag].

Scarlett, R. 1958. 'Obsidian'. New Zealand Archaeological Association Newsletter 2 (1):3.

Seligmann, C. 1910. The Melanesians of British New Guinea. Cambridge: Cambridge University Press.

Seligmann, C and TA Joyce. 1907. 'On prehistoric objects in British New Guinea'. In Anthropological essays presented to Edward Burnett Tylor in honour of his 75th birthday Oct. 2 1907, 325-341. Oxford: Clarendon Press.

Seligmann, C and W Strong. 1906. 'Anthropogeographical investigations in British New Guinea'. Geographical Journal 27 (3):225-242, 27 (4):347-369.

Sheppard, P. 1996. 'Hard rock: Archaeological implications of chert sourcing in Near and Remote Oceania'. In Oceanic culture history: Essays in honour of Roger Green, edited by J Davidson, G Irwin, F Leach, A Pawley and D Brown, 99-115. New Zealand Journal of Archaeology Special Publication. Dunedin: New Zealand Journal of Archaeology.

Skinner, H. 1933. 'Greenstone in the Cook group'. Journal of the Polynesian Society 42 (3):225-226.

Skinner, H. 1953. 'An argillite adze from Taranaki'. Journal of the Polynesian Society 62 (1):81-83.

Smith, WC. 1963. 'Jade axes from sites in the British Isles'. Proceedings of the Prehistoric Society 34:133-172. doi.org/10.1017/S0079497X00015371.

Specht, J, I Lilley and J Normu. 1981. 'Radiocarbon dates from West New Britain, Papua New Guinea'. Australian Archaeology 12:13-15.

Specht, J, I Lilley and J Normu. 1983. 'More on radiocarbon dates from West New Britain, Papua New Guinea'. Australian Archaeology 16:92-95. 
Spoehr, A. 1957. Marianas prehistory: Archaeological survey and excavations on Saipan, Tinian and Rota. Fieldiana Anthropology 48. Chicago: Field Museum of Natural History.

Spriggs, M. 1985. "A school in every district": The cultural geography of conversion on Aneityum, Southern Vanuatu'. Journal of Pacific History 20 (1 \& 2):51-64. doi.org/10.1080/0022334850857 2503.

Spriggs, M. 1987 [orig. 1981]. Vegetable kingdoms: Taro irrigation and Pacific prehistory. Ann Arbor, Michigan: University Microfilms.

Steadman, D. 2006. Extinction and biogeography of tropical Pacific birds. Chicago and London: University of Chicago Press.

Stuiver, $\mathrm{M}$ and P Reimer. 1993. 'Extended ${ }^{14} \mathrm{C}$ data base and revised CALIB $3.0{ }^{14} \mathrm{C}$ age calibration program'. Radiocarbon 35:215-230. doi.org/10.1017/S0033822200013904.

Summerhayes, G. 2009. 'Obsidian network patterns in Melanesia: Sources, characterisation and distribution'. Indo-Pacific Prehistory Association Bulletin 29:109-123.

Summerhayes, G, J Bird, R Fullagar, C Gosden, J Specht and R Torrence. 1998. 'Application of PIXE-PIGME to archaeological analysis of changing patterns of obsidian use in West New Britain, Papua New Guinea'. In Archaeological obsidian studies: Method and theory, edited by M Shackley, 129-158. New York: Plenum Press. doi.org/10.1007/978-1-4757-9276-8_6.

Summerhayes, G, M Leavesley, A Fairbairn, H Mandui, J Field, A Ford and R Fullagar. 2010. 'Human adaptation and plant use in Highland New Guinea 49,000 to 44,000 years ago'. Science 330:78-81. doi.org/10.1126/science.1193130.

Thomas, H. 1923. 'The source of the stones of Stonehenge'. Antiquaries Journal 3:239-260. doi.org/10.1017/S0003581500005096.

Thorpe, W. 1929. 'Evidence of Polynesian culture in Australia and Norfolk Island'. Journal of the Polynesian Society 38 (2):122-126.

Torrence, R [and 11 others]. 2004. 'Pleistocene colonisation of the Bismarck Archipelago: New evidence from West New Britain'. Archaeology in Oceania 39:101-130. doi.org/10.1002/j.1834-4453.2004. tb00568.x.

Turner, F. 1935. 'Geological investigation of the nephrites, serpentines, and related "greenstones" used by the Maoris of Otago and South Canterbury'. Transactions of the Royal Society of New Zealand 65:187-210.

Valentin, F, S Bedford, H Buckley and M Spriggs. 2010a. 'Lapita burial practices: Evidence for complex body and bone treatment at the Teouma Cemetery, Vanuatu, Southwest Pacific'. Journal of Island and Coastal Archaeology 5:1-24. doi.org/10.1080/15564891003648092.

Valentin, F, H Buckley, E Herrscher, R Kinaston, S Bedford, M Spriggs, S Hawkins and K Neal. 2010b. 'Lapita subsistence strategies and food consumption patterns in the community of Teouma (Efate, Vanuatu)'. Journal of Archaeological Science 37:1820-1829. doi.org/10.1016/j.jas.2010.01.039.

Valentin, F, E Herrscher, S Bedford, M Spriggs and H Buckley. 2014. 'Evidence for social and cultural change in Central Vanuatu during the first millennium BC: Comparing funerary and dietary patterns of the first and later generations at Teouma, Efate'. Journal of Island and Coastal Archaeology 9 (3):381-399. doi.org/10.1080/15564894.2014.921958.

Verhofstad, J. 1966. 'Glaucophanitic stone implements from West New Guinea (West Irian)'. Geologie en Mijnbouw 45:291-300. 
Vial, L. 1940. 'Stone axes of Mount Hagen, New Guinea'. Oceania 11:158-163. doi.org/10.1002/ j.1834-4461.1940.tb00282.x.

Warren, SH. 1919. 'A stone axe factory at Graig-Lwyd, Penmaenmawr'. Journal of the Royal Anthropological Institute 49:342-365.

Warren, SH. 1921. 'Excavations at the stone axe factory of Graig-Lwyd, Penmaenmawr'. Journal of the Royal Anthropological Institute 51:165-199.

Weisler, M (ed.). 1997. Prehistoric long-distance interaction in Oceania: An interdisciplinary approach. NZAA Monograph 21. Auckland: New Zealand Archaeological Association.

White, A, T Worthy, S Hawkins, S Bedford and M Spriggs. 2010. 'Megafaunal Meiolaniid horned turtles survived until early human settlement in Vanuatu, Southwest Pacific'. Proceedings of the National Academy of Sciences 107:15512-15516. doi.org/10.1073/pnas.1005780107.

White, JP. 1967. 'Ethnoarchaeology in New Guinea: Two examples'. Mankind 6:409-414.

White, JP. 1968. 'Fabricators, outils écaillés or scalar cores?' Mankind 6:658-666.

White, JP. 1972. Ol Tumbuna: Archaeological excavations in the eastern Central Highlands, Papua New Guinea. Terra Australis 2. Canberra: Department of Prehistory, Research School of Pacific Studies, The Australian National University.

White, JP and J O'Connell. 1982. A prehistory of Australia, New Guinea and Sahul. Sydney: Academic Press.

White, JP, K Crook and B Ruxton. 1970. 'Kosipe: A Late Pleistocene site in the Papuan Highlands'. Proceedings of the Prehistoric Society 36:152-170. doi.org/10.1017/S0079497X00013128.

White, JP, N Modjeska and I Hipuya. 1977. 'Group definitions and mental templates: An ethnographic experiment'. In Stone tools as cultural markers: Change, evolution, complexity, edited by R Wright, 380-390. Canberra: Australian Institute of Aboriginal Studies.

Wickler, S and M Spriggs. 1988. 'Pleistocene human occupation of the Solomon Islands, Melanesia'. Antiquity 62 (237):703-706. doi.org/10.1017/S0003598X00075104.

Willey, G. 1953. Prehistoric settlement patterns in the Viru Valley, Peru. Bureau of American Ethnology Bulletin 155. Washington DC: Bureau of American Ethnology.

Worthy, T, S Hawkins, S Bedford and M Spriggs. 2015. 'Avifauna from the Teouma Lapita Site, Efate Island, Vanuatu, including a new genus and species of megapode'. Pacific Science 69 (2):205-254. doi.org/10.2984/69.2.6. 
This text is taken from Archaeologies of Island Melanesia: Current approaches to landscapes, exchange and practice, edited by Mathieu Leclerc and James Flexner, published 2019 by ANU Press, The Australian National University, Canberra, Australia.

doi.org/10.22459/TA51.2019.02 